DOI https://doi.org/10.36059/978-966-397-162-9/1-31

\title{
PECULIARITIES OF REGULATION OF ACTIVITY OF PUBLIC AUTHORITIES IN THE CONDITIONS OF DECENTRALIZATION
}

\section{Alla Bashtannyk}

\section{INTRODUCTION}

In the conditions of decentralization of power, approaching the European principles of public administration, goals and objectives are being transformed, the main functions of public authorities are being implemented, development strategies of the Ukrainian state are being determined. The formation and development of the system of public authorities in the context of reforms requires a theoretical and methodological justification of the directions of the state, a normative definition of the functions, structure, powers of the authorities, the consolidation of an algorithm for regulating the activities of authorities. It was the decentralization of power that determined the need for the formation of fundamentally new forms and means of regulating the activities of public authorities.

The relevance of the study of mechanisms for regulating the activities of public authorities (regulatory mechanisms) is due to the fact that in modern conditions of the state it is important to form a rationally constructed model of state power that is able to implement public administration functions and ensure the provision of management services. The need to improve regulatory mechanisms is due to constitutional, administrative and judicial reforms in Ukraine, the implementation of the European integration policy, and the special conditions of the modern state. Institutional sphere requires adaptation of its own methodological content, adaptation of European experience in regulating public relations, and introducing innovative regulatory mechanisms.

The research directions of Russian scientists were addressed by the institutional aspects of regulating the activities of authorities in the 
context of transformation processes at the regional level of the state, national state and EU institutions. But they demanded an independent study of the conceptual foundations of the formation of structural characteristics and trends in the organizational development of mechanisms for regulating the activities of public authorities in the field of public administration science. The little studied directions in modern science turned out to be the principles of formation, classification, concepts and models, normative consolidation, social adaptation of regulatory mechanisms.

The purposer of the study is the theoretical and methodological substantiation of mechanisms for regulating the activities of public authorities and the development of practical recommendations for their improvement in decentralization, achieved by solving the following tasks: to analyze the nature and characteristics of the functioning of regulatory mechanisms in the public administration in the context of decentralization of power in Ukraine; highlight the properties of such mechanisms from the standpoint of public administration and administration; establish the place and role of regulatory mechanisms in the implementation of the basic tasks and functions of public administration at the national state level; to systematize modern approaches to the distribution of managerial powers between different levels of regulation under decentralization in accordance with the principles of multi-level management.

Scientific novelty lies in a comprehensive scientific study of the foundations of the formation of mechanisms for regulating the activities of public authorities, the development of practical recommendations for their improvement, which together solve important tasks of reforming public administration. On this basis, the essence, content, features and directions of improving regulatory mechanisms under decentralization are conceptually substantiated; defined the regulation and structure, legal, administrative and institutional foundations of the formation and functioning of regulatory mechanisms under the influence of internal and external factors, social factors, modern challenges in the functioning of the public administration system. 


\section{Methodological bases of the analysis of mechanisms of regulation of activity of public authorities in the field of public administration science}

In the field of public administration science, the content of the specialty "public administration mechanisms" defines theoretical and methodological substantiations of public administration mechanisms, administrative and organizational areas of the state, functions, structure, powers and characteristics of public authorities at all levels ${ }^{1}$. At the same time, the statement of the problem of scientific research of management and regulation of the activities of bodies and institutions of state power requires its own methodological support, analysis of the state power system, formalization of governance models and determination on this basis of the country's development directions. Indeed, under the conditions of decentralization of power in Ukraine, approaching the European principles of public administration, the goals and objectives of the state, the functions of public authorities, and its development strategies are being transformed.

Thus, we are talking about changing the foundations of the functioning of public administration mechanisms, supplementing the principles of regulating the activities of public authorities, the foundations of the formation of public policy, the development of a specific region (interregional complex), industry, and in the broad sense, even public spheres. That is why the mechanisms for regulating the activities of public authorities currently require their own methodological content by developing categories and concepts, laws and principles, systematizing the methods of such regulation, developing concepts and models for regulating the activities of public authorities. At the same time, it requires its own theoretical content to formalize the goals, tasks and functions of the state, its development

Averjjanov V. (2009) Ljudynocentrystsjka ideologhija jak osnova reformuvannja ukrajinsjkogho administratyvnogho prava v umovakh integhracijnogho procesu [Center-centered ideology as a basis for reforming Ukrainian administrative law in the context of the integration process]. Derzhava ta reghiony (Serija: Pravo), 2010, no. 2, p. 87. 
strategy as a factor in the functioning of public administration mechanisms.

It is important to note that the methodological basis of the legal aspect of the mechanism of public administration is the organizational and institutional essence of the mechanisms, the subject-object relationship of government. So, V. Averyanov defines the system of executive bodies, the essence of legal norms in such a system as the constituent elements of a mechanism, and at the same time indicates that it is through the mechanism of state administration that power is exercised $^{2}$.

G. Atamanchuk defines the mechanism of public administration as a complex system of state bodies, structured on the basis of the implementation of public administration tasks. At the same time, while studying the public administration system, G. Atamanchuk identifies such inherent characteristics of its structure: firstly, interaction within the framework of the system "management subject (state) relationships (direct and feedback) - public system"; secondly, the analysis of the system "subject of management - impact - object of management"3. Also, this researcher defines the legal status, organizational structure, system of external relations as the main features of an authority ${ }^{4}$.

In particular, on the basis of an analysis of the definitions of domestic and foreign scientists, V. Prikhodko proposed his own definition of the mechanism of public administration as a system designed for the practical implementation of public administration and

2 Averjjanov V. (2009) Ljudynocentrystsjka ideologhija jak osnova reformuvannja ukrajinsjkogho administratyvnogho prava $\mathrm{v}$ umovakh integhracijnogho procesu [Center-centered ideology as a basis for reforming Ukrainian administrative law in the context of the integration process]. Derzhava ta reghiony (Serija: Pravo), 2010, no. 2, p. 92.

3 Atamanchuk Gh. (2005) Ghosudarstvennoe upravlenye (orghanyzacyonnofunkcyonaljnye voprosy) : ucheb. posob. Moskwa [Public Administration Theory: A Lecture Course]. Omega-L (in Russian).

${ }^{4}$ Atamanchuk Gh. (2000) Ghosudarstvennoe upravlenye (orghanyzacyonnofunkcyonaljnye voprosy): ucheb. posob. [Public administration (organizationalfunctional issue): textbook. help]. Moskwa. Legal literature (in Russian). 
the achievement of goals, which has a certain structure, methods, levers, instruments of influence on the management object with the legal, regulatory, information support. The same researcher suggests defining the mechanism of state regulation as a set of functions, stages and sequential procedures of regulatory influence on the organizational system, accompanied by the achievement of a certain result of this action, which can be compared with indicators to determine the level of achievement of the managerial (program) goals of the system ${ }^{5}$.

O. Radchenko defines the essence of the mechanism of public administration as “... a system of institutions, structures, sequential actions, forms, conditions and processes in the state as a product of organized human activity, aimed at realizing the interests and needs of people and solving pressing socio-political problems with account of state influence and regulation of public life on the basis of established social values, norms and rules; is a form of realization of the functions of the state and has as a subject government bodies ${ }^{6}$. O. Korotich proposed a new methodological approach to the structuring of the system of state governance mechanisms and government governance mechanisms, introduced the concepts of "target government governance mechanism" and "public administration process mechanism". The researcher considers the term "government control mechanism" to be the broadest concept ${ }^{7}$. Separating the approaches of O. Korotich to the classification of the mechanism of public administration as a whole, we consider it appropriate to note that the concept of mechanisms (management, regulation) in the social

5 Prykhodjko V. (2013) Mekhanizm derzhavnogho reghuljuvannja ta upravlinnja ekonomichnoju bezpekoju [The mechanism of state regulation and management of economic security]. Investyciji: praktyka ta dosvid. no. 15. pp. 6-8.

${ }^{6}$ Radchenko O. (2013) Rodovi oznaky kateghoriji mekhanizm v socialjnykh naukakh [Generic attributes of the mechanism category in the social sciences]. Publichne upravlinnja: teorija ta praktyka, № 3. pp. 19-25.

7 Korotych O. (2006) Derzhavne upravlinnja reghionaljnym rozvytkom Ukrajiny [Public Administration of Regional Development of Ukraine ] Kharkiv:. Maghistr. (in Ukrainian). 
sciences is quite broad, but the design of the "mechanism - process" looks somewhat controversial from the standpoint of characterizing public administration itself.

R. Rudnitska and O. Sidorchuk, analyzing the essence and content of public administration mechanisms, the principles of their functioning, provide definitions of the government mechanism as a quasi-system designed to achieve its goals, which has a certain structure, a set of legal norms, methods, and tools of the state impact on the control object. Moreover, the following are related to the principles of the formation of such mechanisms: determination, continuity and reliability, regularity, dynamism, consistency with the laws of control, integrity, autonomy, modeling. The authors also proposed a generalized model of public administration mechanism ${ }^{8}$. In general, agreeing with the above methodology, we believe that it is important to separate the concept of "mechanism" and "system", they differ not in formal terms (elements, components, interconnection, etc.), but primarily in terms of conceptual content.

It is worth agreeing with the methodological approach of L. Prikhodchenko on the structural-organizational and structuralfunctional determinants of the public administration mechanism ${ }^{9}$ and at the same time pay special attention to the formation and functioning of such a regulatory mechanism that has a clear algorithm for implementing the principles of public administration. Indeed, the main problem of the public administration system is the imbalance in the activities of the components of state power, the absence of socially significant regulators, the uncertainty of the characteristics of the external impact on the management system, and the incompleteness of

8 Rudnicjka R. Sydorchuk O. 2014.Sutnistj ta zmist mekhanizmiv derzhavnogho upravlinnja ta pryncypiv jikh funkcionuvannja [The essence and content of the mechanisms of public administration and principles of their functioning]. Publichne upravlinnja: teorija ta praktyka. no. 4. pp. 50-60.

Prykhodchenko L. (2008) Sutnistj ponjatj mekhanizmiv derzhavy, derzhavnogho upravlinnja ta derzhavnogho reghuljuvannja [The essence of the concepts of mechanisms of the state, public administration and state regulation]. Aktualjni problemy derzhavnogho upravlinnja: zb. nauk.pr. no 3, pp. 269-274. 
the legal design of the fundamentals of activities of the subjects of government.

A significant contribution to the development of conceptual and categorical foundations for the functioning of the mechanism of public administration was made in the works of O. Fedorchak. The author's suggestions on the classification of public administration mechanisms are based on the specific scientific method "mechanism concept public administration concept - public administration mechanism concept". At the same time, the author justifiably explains the differences in the interpretations of scientists about the mechanism of public administration and offers his own definition of the mechanism of public administration as a system designed for the practical implementation of public administration, the achievement of goals that have a certain structure, methods, levers, instruments of influence on the object of government with relevant legal, regulatory and information support. O. Fedorchak supports the position of other authors, in particular R. Rudnitsky and others, regarding the relatively complex nature of the state mechanism (the state mechanism consists of economic, motivational, organizational, political, legal mechanisms). In doing so, the researcher presents her own generalized classification of the mechanism of public administration by distinguishing mechanisms by functional purpose and by management ${ }^{10}$. In our opinion, such a classification is more acceptable in the sense of the category of public administration, and O. Fedorchak developed model of organizational management mechanism in the regional state administration can serve as a basis for developing an integrated model of multi-level management, provided that the region (region) is defined as the basic level of formation of the state mechanism. management.

${ }^{10}$ Fedorchak O. (2008) Klasyfikacija mekhanizmiv derzhavnogho upravlinnja [Classification of mechanisms of public administration]. Demokratychne vrjaduvannja: Naukov. visnyk LRIDU NADU. [Democratic Governance: Scientific. Bulletin of LRIDU NADU] vol. 1. Retrieved from: www.lvivacademy.com_O_Fedorchak.pdf. Accessed (5.11.2019). 
In this format of the perception of regulatory mechanisms, it is important to indicate the general format proposed by V. Kniazev and V. Bakumenko for defining the mechanism of public administration as “... practical measures, means, incentive levers with which public authorities influence society, production, any social a system to achieve your goals" ". Most domestic researchers propose a generalized concept of a "comprehensive mechanism" as a combination of economic, social, organizational, political, legal and other means of influence of public authorities on public relations. At the same time, such a definition is expedient and justifiable also applicable to the regulatory mechanism, since the components of the public administration mechanism are presented precisely because of the regulatory influence of the subject of management. In addition, one should take into account the justified approach of N. Nyzhnyk and A. Mashkova to determine the mechanism of public administration as an integral part of the management system, which provides an impact on factors on the state of which the result of the activity of the administrative object depends ${ }^{12}$. In our opinion, any impact (first of all, subject-object impact) in the government system is determined by the modern paradigm of social regulation, and accordingly it is important to determine the positive dichotomy "governance mechanisms - regulatory mechanisms" in the public administration system.

From the standpoint of the methodology of public administration, it is advisable to determine the characteristics of regulatory mechanisms through the characteristics of the activities of state authorities, in particular, the legal status, structure, interaction with other authorities, determining the influence of the external environment on the regulatory object and subject. Formally, at present,

${ }^{11}$ Knjazjev V., Bakumenko V. (2002) Derzhavne upravlinnja: slovn.-dovidn. [Public administration: vocabulary reference]. Kyiv: UADU. (in Ukraine).

12 Nyzhnyk N. (1998) Systemnyj pidkhid v orghanizaciji derzhavnogho upravlinnja: navch. posib. [Systematic Approach in Public Administration: Tutorial]. Kyiv: UADU. (in Ukraine) 
there are several strategic directions of research in the context of the concept of "public administration mechanism". Firstly, an intheoretical study of public administration mechanisms in a specific sector of the economy. Secondly, studies of the directions and principles of the formation and implementation of state policy in a particular sphere (or industry), providing for the analysis of the emergence, formation and development of integrated regulatory mechanisms as a combination of territorial, sectoral and intersectoral regulation. Thirdly, studies of formally defined mechanisms of state regulation of the development of a country, a region of an industry, programs and mechanisms for their implementation. Fourth, a comprehensive analysis of the functioning of the systems and structures of public authorities (status, goals, objectives, functions, resources), the formation on the basis of such an analysis of the functional regulatory mechanisms. Fifth, research on targeted, organizational, resource and other components of the regulatory process. Sixth, the functioning of regulatory mechanisms at the central, regional and local levels in accordance with the principles of multilevel management. Seventh, an analysis of the institutional economic, legal, social, historical foundations of the functioning of such mechanisms.

For a long time in the scientific community there has been a constant discussion about the distinction between the concepts of "public administration mechanisms" and "state regulation mechanisms", an interpretation of the essence of regulation as a social phenomenon and manifestations of social impact ${ }^{13}$. In particular, revealing the importance of organizational and legal support for the implementation of administrative reform for improving the activities of authorities, the role of the legislative and legislative aspects of the

13 Bashtannyk A. (2015) Konceptualjni zasady naukovogho analizu stanovlennja mekhanizmiv reghuljuvannja dijaljnosti orghaniv vlady $\mathrm{v}$ Ukrajini [Conceptual bases of the scientifically developed structure of regulation of power activity in Ukraine]. Efektyvnistj derzhavnogho upravlinnja: zb. nauk. pr. no. 43. pp. 281-286. 
formation of regulatory mechanisms, it should be pointed out that among the main problems that impede the implementation of reforms is its legislative support, which leads to fragmentation, the gap between the regulatory processes of administrative reform and the processes of whelp organizational measures declared objectives.

At the same time, systematization of mechanisms, forms, structure, approaches and tools for regulating the activities of authorities aimed at implementing such managerial tasks remains unresolved:

1) the need to maintain the highly effective functioning of regulatory mechanisms in the legislative, executive and judicial systems at the central, regional, subregional and local levels of government;

2) the need to form a modern effective system of local selfgovernment; the need to introduce the ideology of the functioning of executive bodies, local self-government as activities to ensure and realize the rights and freedoms of citizens, the provision of state and public services;

3 ) the creation of a modern system of training and retraining of managerial personnel in order to ensure the quality of the functioning of mechanisms for regulating the activities of public authorities in the field of public administration science;

4) improving the legal framework for the implementation of administrative reform, primarily in the format of rationalizing mechanisms for regulating the activities of authorities, etc.

We believe that the category of "mechanisms of state regulation" was studied in the science of public administration mainly from the perspective of a functional approach, within which the basis of the research is the objective-targeted approach, and in fact, government regulation acts as a specific concept with respect to public administration as a generic concept.

The existing definitions of "government regulation" are formulated in the context of specific areas of application, based on an 
industry approach ${ }^{14}$. In this context, it is necessary to highlight the modern research problem associated with the transfer of the industry aspect of the concept of regulation (state regulation, regulation mechanism, etc.) in the general methodological context. So, for example, A. Komyakovim, "the mechanism of state regulation should be considered as a set of organizational and economic methods and tools with which interrelated functions are performed to ensure continuous, effective action in harmonizing the system (state) to increase the functioning of the economy"15.

Accordingly, the basic concept of the theoretical and methodological foundations for the development and functioning of public administration mechanisms is the "regulation" category, which is the main area of research for the specialty 25.00.02 - public administration mechanisms ${ }^{16}$ (despite the fact that the specialty passport provides for only three blocks: 1) state regulation of the development of a country, region, industry, programs and mechanisms for their implementation; 2) mechanisms of state regulation of individual sectors and spheres of public life and their improvement; 3) management and regulation of the activities of bodies and institutions of state power: analysis, modeling and optimization ${ }^{17}$. In a combination of research areas of government regulation mechanisms, it is important to identify research areas that formed the basis for the formation of the modern methodological resource of public

14 Meljnychenko V. (2004) Decentralizacija ta dekoncentracija publichnoji vlady na postradjansjkomu prostori: determinovanistj, znachennja, mezhi [Decentralization and deconcentration of public power in the post-soviet space: determination, meaning, limits ]. Visnyk Khmeljnycjkogho instytutu reghionaljnogho upravlinnja ta prava, no 1-2, pp. 282-288.

${ }^{15}$ Kom'jakov O. (2000) Derzhavne reghuljuvannja perekhidnoji ekonomiky [State control in a transition period economy] (PhD Thesis): Kyiv: Kyiv National Economic University.

16 Higher Attestation Commission (2007) Passports of specialties. HAC Bulletin of Ukraine. no 3. pp. 4-8.

${ }^{17}$ Bakumenko V. (2014) Pidkhid do vyznachennja pasportiv specialjnostej shljakhom systemnogho analizu derzhavnogho upravlinnja [An approach to the definition of specialty passports through a systematic analysis of public administration]. Aspekty publichnogho upravlinnja, no 3-4, pp. 5-9. 
administration science. At the same time, we are the main criterion for the distribution of works of domestic scientists a specific subject and object of study of a particular scientist:

1) public administration at the industry level;

2) industry aspect of the formation of mechanisms of state regulation

3) mechanisms of state regulation of the development of the state, region;

4) state management of regional development (management at the regional level);

5) mechanisms for regulating the activities of authorities in certain areas.

In particular, A. Merzliak proved that one of the most important effective mechanisms of socio-economic transformation is the activation of the investment process by attracting foreign investment. A. Merzliak points out that it is impossible to achieve positive results without defining the investment mechanism of market entities at the macro, meso and micro levels, and notes that investment policy is considered as the most important component of the general economic policy pursued by the state. In addition, it is important to agree with the conceptual approach of A. Merzliak on the role of the European integration vector for Ukraine, the introduction of experience in implementing state policy of the states of the East European space, some of which are related to post-Soviet ones, which leads to similarities in the level of economic development and the problems, goals and objectives facing them ${ }^{18}$. In our opinion, the mechanisms of regulating the activities of state authorities should be understood as the internal structural unity of institutional, organizational, legal and

18 Merzljak A., Scryabina D. (2015) Derzhavna polityka skhidnojevropejsjkykh krajin u sferi jevrointeghraciji:perspektyvy adaptaciji dlja Ukrajiny [State Policy of Eastern European Countries in the Field of European Integration: Adaptation Prospects for Ukraine] Teorija ta praktyka derzhavnogho upravlinnja ta miscevogho samovrjaduvannja [The theory and practice of public administration and local self-government] (electronic journal), no. 1. Retrieved from: http://el-zbirn-du.at.ua/2015_1/13.pdf. Accessed (5.11.2019). 
administrative means, forms and methods in the state administration system, a rational combination of which on the basis of a systematic approach allows you to change the usual regulation of the behavior of objects and subjects of management objects on the regulatory impact of the subject regarding social relations.

The given model allows us to characterize the regulatory mechanisms from the standpoint of:

1) semantic context - the definition of a mechanism as: a system; complex; totality; structural unity and on this basis the wording of the author's definition of the mechanism for regulating the activities of public authorities;

2) a functional context - the definition of a mechanism through a comprehensive analysis of means, forms, methods, functional features, implementation tools, management algorithms and, on this basis, the development of directions for streamlining the activities of state authorities;

3) institutional context - the definition of subjects, objects and objectives of regulation and, on this basis, the development of the format of an integrated regulatory mechanism;

4) the administrative context - the definition of the essence of the regulatory impact in the system of public authorities, the formulation on this basis of the conceptual framework for the functioning of regulatory mechanisms in decentralization.

So, the methodology for studying the process of formation and development of public administration mechanisms, and accordingly the mechanisms for regulating the activities of public authorities, should be based on an integrative combination of the political and legal foundations of the functioning of public authorities, the institutional features of the functioning of public administration mechanisms, the establishment of organizational characteristics of subjects and regulatory objects authorities, analysis of administrative procedures how about new regulation. From these positions, it is important, first of all, to focus on ensuring the needs of the subjects and objects of management in the regulatory impact, which should be fixed by the principles of regulation and special regulations containing individualized (specific) 
characteristics of regulation. Moreover, the general structure of the study of the mechanism for regulating the activities of public authorities requires the solution of such research problems:

- the development of theoretical and methodological foundations for the development of mechanisms for managing the activities of authorities at different levels within the national state, the identification of historical trends in the formation of the political and legal framework for regulating power relations in Ukraine as an independent direction of the science of public administration;

- systematization of the European experience of rationalizing regulatory mechanisms through the use of modern methodology of scientific research, based on the principles of multi-level management, complementarity of the components of the state (public administration) system;

- clarification and addition of the conceptual and categorical apparatus regarding the activities of subjects of public relations in the field of regulation of public authorities through the tasks, goals, principles, competencies of political institutions, as well as finding out the place of authorities in complex administrative systems;

- development of the conceptual foundations of the formation of an innovative regulatory mechanism that meets modern concepts of "Good governance" and "New public management".

In the context of the "reset of power" process, it is important to determine the key characteristic of the regulatory mechanism itself the stability of such regulation, the principles and principles of regulation, the continuity of constitutional norms that determine the status of subjects of regulation of the activities of state authorities. At the same time, the process of reforming public administration should be determined by research: firstly, both the predicted and the spontaneous factors (regulators) of internal and external impacts on social relations stabilize the country's political system; secondly, the organizational means of improving the management system at the level of the national state, if the individual criteria of social reforms are not known in advance, are formed under the influence of changes in the political course and act as an element of rationalization of public 
authority. So, formally we are talking about the search for such a socially significant regulator that will be able to clearly determine the necessary direction of development of the public administration system in the new political conditions, and at the same time maintain a certain continuity of the country's political course. In this context, the question arises about the essence of modern reform of public administration as a certain imperative of public policy in an integrated form, which determines, in fact, the vector of reforms.

Under such conditions, changes have taken place in the modern concept of the activity of authorities, including through the implementation of the European principles of public administration in accordance with the concepts of "New public management" and "Good governance". After all, the modern European principles of public administration, the universally recognized democratic values of European civilization (rule of law, democracy, human rights) ${ }^{19}$ serve as a guideline for the implementation of public administration reforms, determine the essence of modernization of public administration in the political and administrative sense by creating innovative regulatory mechanisms in public administration system. At the same time, the construction of innovative regulatory mechanisms provides for the determination of the historical foundations of the formation of such mechanisms. The application of the historical method in the study is due not only to the advisability of developing an accurate periodization of the formation of management mechanisms in Ukraine, but also to updating the determination of specific (special) conditions for the functioning of regulatory mechanisms at a particular historical stage, establishing patterns and trends in the development of mechanisms at the national and regional levels, and determining at this the basis of priority directions of the state.

${ }^{19}$ Shevchuk B. (2012) Jevropejsjki pryncypy nalezhnogho vrjaduvannja ta reforma systemy orghaniv vykonavchoji vlady v Ukrajini [European principles of good governance and reform of the executive power system in Ukraine]. Demokratychne vrjaduvannja. [Demokratychne vrjaduvannja] (electronic journal), no. 9. Rezhym from: http://www.lvivacademy.com/visnik9/fail/Shevchuk_B.pdf. Accessed (5.11.2019). 
The modern methodology for studying regulatory mechanisms also provides for the use of a comparative analysis of the activities of authorities in Ukraine and foreign countries. Such an analysis is based on the principles of the innovation paradigm of public administration: a combination of constitutionally established procedures for public administration and the components of social management; development of democratic principles of state regulation, institutionalization of public influence on the adoption of public management decisions in the development of public policy; objectivity, accessibility, completeness and efficiency of information; rational organization of the management apparatus; development planning and forecasting; conducting personnel policies in government based on the principles of professionalism; guarantee of legality and control over the implementation and compliance with laws. It should be noted that such an innovative paradigm proceeds from the modern interpretation of public administration as an integrative combination of managerial activity of public servants and persons holding political positions, institutional unity of structure and procedures in the system of public authorities. Public administration includes activities that ensure the effective functioning of the entire system of public authorities and local authorities and provide for the wide involvement of various stakeholders in the development and implementation of public policy. The conceptual diagram of the study of the functioning of the regulatory mechanism is presented in Fig. 1.

The given conceptual scheme reflects the regulation algorithm based on optimization criteria in complex administrative systems. Indeed, in the conditions of the transformational development of Ukraine, the urgent problem of the science of public administration is the development of conceptual provisions for the implementation of the foundations of public administration, the meaning of which is to create an effective system of government by providing guaranteed protection and harmonious socially-oriented development of the governance system and the totality of public relations. This requires ensuring the possibility and ability of public administration entities to form capable regulatory mechanisms at all levels of the territorial 
organization of the state. At the same time, integrated mechanisms for regulating the activities of state authorities (as a result of modern administrative reform) should function even with unfavorable options for the development of internal and external processes.

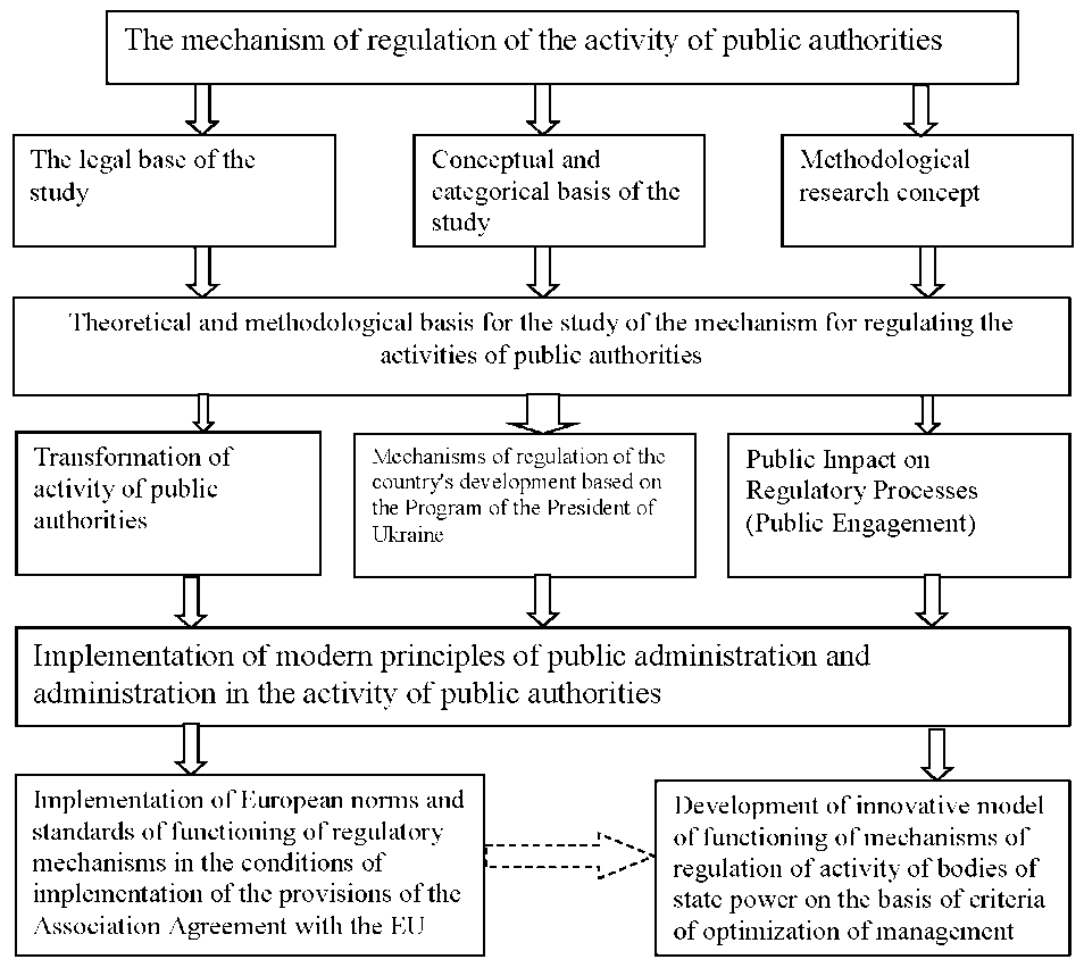

\section{Fig. 1. The conceptual scheme of the study of the functioning of the regulatory mechanism}

It should be noted that the mechanism for regulating the activities of public authorities is characterized by the presence of a set of interconnected components of a theoretical, methodological, organizational and institutional nature. The construction of a democratic, rule-of-law state requires the formation of appropriate scientific support for the implementation of reforms, initially based on advanced research models to improve public administration. 


\section{The conceptual framework for the functioning of mechanisms for regulating the activities of public authorities in Ukraine in decentralization}

The democratic transformations taking place in Ukraine, the intensification of the processes of formation of civil society institutions and the building of a democratic, social, legal state require the optimal combination of political, social, economic, cultural trends in modernizing modern Ukrainian society and effectively improving the mechanism of state power.

The formation of a sovereign, independent, democratic, social, legal state in Ukraine (Article 1 of the Constitution of Ukraine) objectively updated not only the principle of separation of powers, but also served as the normative basis for the scientific and pragmatic legalization of state power and local self-government (Article 5 of the Constitution of Ukraine). The institutional change of any element in the system of state power leads to the transformation of the entire system of power relations and contributes to the formation of a fundamentally new regulatory mechanism.

The system of public authorities includes structural changes in regulatory mechanisms from the standpoint of institutional regulation of the activities of authorities in combination with organizational changes and the adoption of internal regulations. From the perspective of historical analysis, it is necessary to define the concept of the state as a sovereign administrative-territorial organization of politically institutionalized power, within the framework of which there is formed: a functional administrative apparatus, an effective enforcement apparatus, a rational law-making mechanism and law enforcement aimed at the implementation of state power at all levels of government. Moreover, the mechanism of the state acts as a structurally integrated set of components of the state power system.

That is why the primary task of studying regulatory mechanisms is to determine the structure and characteristics of the activities of state authorities at all levels. The public authority is a functionally, organizationally and structurally autonomous element of the state apparatus (national government management mechanism), is endowed 
with a legislatively established set of powers (direct and delegated) in accordance with the intended purpose, consists of structural units and posts that hold public servants, and is referred to by the Constitution of Ukraine and the laws of Ukraine in the system of public authorities. This is the functional feature of a public authority: this is created with the goal of directly implementing a specific type of government activity; performs activities characterized by a clearly defined state orientation, goals, tasks and functions, a certain amount of competence (rights and obligations); carries out its activities using methods and forms defined by the state; has a certain legal form, internal structure and external relations.

Classification of types of government bodies is carried out according to various criteria: according to the criterion of legal level higher, central, local; by the nature of competence (content of functions) general, sectoral, functional or mixed competence; in terms of scope - to the governing bodies of the economy, socio-cultural development, in the administrative and political sphere; by the method of making power decisions - to collegial and solely educational (sole) the like.

The system of government is characterized by the isolation of the corresponding group of government bodies that are part of a particular system from other types of government bodies; clearly defined composition of the system; the presence in the aggregate of the relevant state bodies of certain characteristics inherent in complex social systems, such as unity of purpose, functional self-sufficiency, hierarchy of organization, subordination, the relationship between structural units and the like. This is especially true for the development and adoption of management decisions, which are not only preceded by the collection and processing of information, but which themselves contain great information potential.

From the standpoint of establishing the purpose of regulatory mechanisms at various stages of the state, it should be pointed out that attempts to use the Soviet-style state apparatus with unprepared for this managerial staff could not be used to solve the tasks of regulating the activities of state authorities and the formation of new mechanisms of state governance in the independent Ukraine give positive results. Indeed, systemic crisis phenomena in the economic and social spheres 
of world social development testify first of all to the inefficiency of recent attempts to transform the public (state) management system in Ukraine in accordance with new political and ideological guidelines and socio-economic transformations. Unfortunately, governance at the national level and at the level of such a specific management object as the region turned out to be inappropriate public relations that have changed. At the same time, the organization of the administrativeterritorial structure of Ukraine has significant shortcomings that impede the acceleration of the transformation of public administration to a higher quality level, slow down the reform of public administration, and do not comply with European standards for the proper administration of a modern state.

In modern conditions, a significant part of the administrativeterritorial units is deprived of financial and economic resources, as well as the power to implement the principle of decentralization of governance regarding the socio-economic development of the state (as well as the region as a special management object). In order to put into practice the general principles of the structure of Ukraine as a unitary, in the constitutional sense, decentralized state, it is necessary to rationalize the state structure and administrativeterritorial division, abandon the mechanical identification of regions with regions, and constitute regions that are really composed on the basis of economic, demographic, cultural and other features and at the regional level to create a really working management system. In fact, the task of developing a universal management concept is being actualized - the formation of mechanisms for regulating the activities of public authorities based on the integration of management levels, optimizing the interaction of management institutions, and legal regulation of the purpose of regulatory mechanisms. Indeed, the content of public administration is often understood as the activity of the state, with the exception of the activities of the legislative branch and the judiciary. Such a negative formal definition does not reveal the essence of public administration, its purpose. 
Currently, it is precisely the problems of rationalizing the organizational and legal support for reforming public administration in the context of the transformation of the political system of Ukraine that actualizes a systematic approach to the activities of public authorities and management, establishing a socio-political dialogue, introducing European experience in adapting to supranational integration processes, developing local and regional systems self. Conducting a comprehensive reform of the power system in the context of accelerating integration processes in Europe, justified by the need to generalize historical, theoretical and practical knowledge in the field of public administration, develop practical recommendations and develop a system of effective means of implementing government and administrative influence in specific historical conditions of the transition period, the formation of prerequisites for the existence of civil society in Ukraine.

Given that the control object acts as a determining factor for the control subject, that is, it affects its construction, behavior, activity, choice of goals and the use of the entire array of means to achieve them, it is he who determines the form of power regulation that is adequate to him. That is why the formation and development of regulatory mechanisms is due to the modern approach to transformation processes in the public administration system, the transition in such a management system to the implementation of the principle of decentralization as the basis for modernization of the state. The study of the place and role of decentralization processes in the formation of democracy in society is becoming of paramount importance for both state-organizational processes and modern Ukrainian practice. Indeed, in the modern world there are no absolutely stable social organisms, because we are witnesses to the dynamic development of society. And if the corresponding dynamics of social development is large-scale, they usually speak of a transitional stage or transitional period. That is why they use the concept of a transitional society as a society in a state of transformation of the basic components of the political system.

Transformational changes are inherent not only in postcommunist countries as a transition from totalitarianism to democracy, 
but as the realization of a "democratic transition" in a society that carries out evolutionary transformation from one qualitative state to another, and it is in this process of transformation that a qualitatively new type of relationship arises. In this case, each sovereign state that implements transformational transformations should look for its optimal way to enter the global context, and at the same time integratively combine global positive experience, and its own traditions and peculiarities of adaptation of universal values ${ }^{20}$.

The content of the formation of regulatory mechanisms at the present stage of the creation of the state is the theoretical and methodological justification of public administration, the administrative and organizational directions of the state, structures, powers and features of public authorities. Administrative and organizational support for the formation of mechanisms for regulating the activities of public authorities should be defined as a system of interrelated elements: 1) goals and objectives of the state; 2) the state of the regulatory process, which is desirable to achieve in the process of developing legal norms governing the functioning of such a mechanism; 3) regulatory support for the development of public relations arising between the components of the state power system, between government at the state and regional levels. Under such conditions, each of the elements of the regulatory system is considered from the standpoint of a system-functional analysis, that is, as a component of the mechanism with its inherent functions, as well as an independent subsystem of authorities performing the functions established by the norms of legislation.

Since public authority by its nature tends to be centralized, the task of combining the principles of decentralization and subsidiarity in the functioning of regulatory mechanisms is becoming more relevant. Under certain conditions, the state is trying to increase its influence on public relations, even under the condition of a declarative strengthening

${ }^{20}$ Rebkalo V., Shkljar L. (2003) Politychni instytuty v procesi reformuvannja systemy vlady [Political institutions in the process of reforming the system of government]. Kyiv: Milenium. (in Ukraine). 
of the role of self-governing structures. First of all, such a phenomenon manifests itself in the form of concentration of the overwhelming majority of managerial functions at the central level of power by creating special and special regulatory mechanisms. The concentration of state power (centralization) is a fairly common managerial ideology in modern political systems. However, in the absence of effective regulatory subsystems, such a process will not be implemented if functional regulatory mechanisms do not work. That is why, in order to restore the optimal state of public power, modern European countries resort to decentralization of power. As part of this process, the redistribution of power and competencies between the central and local levels of public authority is carried out with a shift in emphasis to the local level in the implementation of functions predefined and guaranteed by the state. But European countries always began such a process with the formation of qualitatively functioning regulatory mechanisms.

That is why the main tasks of the formation of regulatory mechanisms should be defined in the format of the Concept for improving the mechanisms for regulating the activities of public authorities under decentralization: firstly, the identification of the components of the formation of such mechanisms in the system of public management activities; secondly, the introduction of a single, coordinated mechanism for the functioning of the system of legal support of state authorities, including: ensuring effective interaction and coordination of actions of state bodies, civil society institutions and citizens in this area, introducing a systematic approach to planning, resource support and control over the activities of authorities; thirdly, ensuring the effective functioning of monitoring the effectiveness of power, including a clear definition: the concept of a regulatory mechanism, a public administration mechanism; special and integrated regulatory mechanisms; adoption of regulatory legal acts based on the results of activity of the authorities.

In our opinion, the above conceptual approach is especially relevant in conditions of decentralization of power, since it requires clarifying the features of the development of decentralization processes, theoretical justification of the ways of reforming the public 
administration system and local self-government, adapting the public administration system of Ukraine with international standards of modern public administration, determining the essential characteristics of governance from the standpoint of regulation of the activities of authorities in a system many reforms. According to the main features (the source of power, the nature of the interaction between the subject and the control object, the nature of social norms), within the framework of a decentralized management system, public authorities carry out a regulatory impact on public relations. From such positions, it is advisable to talk about the effectiveness of decentralization in the context of the ability of authorities to implement the national reform policy.

\section{CONCLUSION}

The current state of socio-political development of Ukraine, the influence of the processes of modernization of power and Europeanization of governance on the public administration system require a conceptual review of the established patterns of relations between public authorities and civil society institutions, updating the entire government system. In these circumstances, decentralization as a modern challenge to the sustainability of governance requires the formation of an innovative model of the organization and functioning of public authority at the national, regional and local levels in the constitutional dimension objectified through the implementation of the principle of subsidiarity.

The relevance of the study of the processes of centralization and decentralization from the standpoint of their dichotomous relationship and impact on functioning is due to the solution of the problem of the effectiveness of state power in the context of the components of state power, levels of government and authorities as structural and functional units. The ability of state power to form innovative regulatory mechanisms in decentralized conditions characterizes the sovereignty of state power in the face of modern challenges. The process of decentralization is due to the modern approach to 
transformational processes in the public administration system, the need to rationalize management.

From the standpoint of developing a methodological concept for studying the processes of decentralization and the peculiarities of the formation of regulatory mechanisms, attention should be paid to the systematization of research approaches to decentralization as a process and phenomenon, highlighting the characteristics inherent in complex administrative systems, revealing the essence and structure of subjects of decentralization of power, analyzing the international experience of decentralization through determination European principles and standards of decentralization of power, in including as a structural and functional factor in the development of social relations, the development of a model of interaction "state - society". In this sense, decentralization of power should be understood as an institutionally determined procedure for political and legal approval of the rights and capabilities of administrative-territorial units and their administrative bodies to ensure rational management of the territory. In this process, the delegation of authority takes on a vertical direction, and involves the transfer of authority in part - from the center to the local level, and in part from the local level to the central level of public administration.

In this format, decentralization of power is not only a component of the reform of public administration, but it actually provides a subject field for studying regulatory mechanisms from the standpoint of determining the purpose, principles and content of regulation, the structural structure of such mechanisms, essentially changing the standard model of territorial administration to a model of multilevel management, within a nation state. In most modern studies (A. Batanov, V. Bordenyuk, V. Groysman, I. Drobot, etc.) the formalized dualistic model of decentralization in the framework of the system of "state power - local self-government". Such a model is based on two approaches that complement each other. The first approach involves maintaining the role of the state as an integrating factor in the process of creating the state, which provides a transformational model of the country's development; the second approach provides for the transfer of authority from government to local authorities (in accordance with the 
legal mechanism for securing authority in a particular area). In our opinion, the formation of modern regulatory mechanisms requires the solution of a basic managerial task: ensuring the functioning of public authorities to provide public services, satisfying the public interest, developing and implementing public management decisions. Moreover, there is a functional model of decentralization formulated within the framework of the modern traditional approach to this process as a combination of federalization, regionalization, municipalization.

An increase in the effectiveness of public administration in Ukraine is possible through the improvement of the forms, methods and mechanisms of public authorities based on the adaptation of the domestic theory of management of the development of administrativeterritorial entities in accordance with the principles of the EU regional policy and the introduction on a national basis of pan-European management traditions in accordance with the concept of the modern European integration process "From Europe of states to Europe of regions". In the framework of the post-Soviet state-administrative tradition of analyzing centralization processes, most domestic scholars focus on centralism as an institutional factor, which led to a deformation in the system of separation of powers, the only center of which remains the president of the country.

The dichotomy in the system of "centralization decentralization" has always characterized the capacity of state institutions to exercise certain powers, to ensure that the Constitution of Ukraine respects fundamental rights and freedoms. However, with the development of the state, semi-autonomous subsystems with a quasiinteraction function were formed in the system of public authorities at various levels. In fact, within the functioning of such subsystems, the coordination function of management is minimized, and the regulatory mechanism is formalized exclusively through legal regulation.

That is why the developments of a fundamentally new concept of regulating the activity of government bodies are updated, which provides: firstly, the functioning of integrated mechanisms for regulating the activities of government bodies based on the formation of effective vertically integrated subsystems of government bodies; 
secondly, the modernization of the institution of public service in the context of the concept enshrined in the Code of Administrative Procedure of Ukraine; thirdly, improving the activities of government bodies in creating a mechanism for the provision of public services to satisfy the interests of citizens (imperative of public interest) fourthly, creating a mechanism of political and public control over activities. In modern conditions, it is important to point out the emergence of a new concept of regulation of activities of state authorities in reforming the administrative-territorial structure of Ukraine.

The development and formation of modern mechanisms of public administration as an integral science involves the thorough development of a conceptual and categorical apparatus, whose task is to integrate the main categories, terms and concepts that determine the essence of a certain type of managerial activity and reproduce the most significant, regular managerial relations and relationships. Such categories are the basis of the theoretical and methodological substantiation of management mechanisms and regulation of the fundamentals of management activities, determine the level of adaptability of management systems to regulatory impact, and contribute to the systematization of scientific and practical approaches. So, the reform processes in the system of public authorities require a certain systematization and refinement of the wording, content and interpretations of such concepts, the structuring of scientific categories by content.

\section{SUMMARY}

The paper deals with theoretical and methodological grounds and development of practical recommendations to improve the institutional, administrative and organizational-legal mechanisms of regulation of the public authorities' activity in the context of the administrative reform. The system analysis of the essence and functioning of regulation mechanisms of the public authorities' activity is made; the peculiarities of the conceptual-categorical apparatus formation of the research are defined. The paper studies contemporary foreign (European) models of functioning of regulation mechanisms of the public authorities' activity, determines the place 
and role of the regulation mechanisms in implementation of the basic tasks and national state functions; the modern approaches to distribution of administrative powers between various levels of regulation mechanisms of the public authorities' activity in accordance with the principles of the delegated administration are systemized.

The approaches to solve the problem of the dichotomy of scientific categories "mechanisms of regulation" and "state regulation" are offered in the paper. The definition of the mechanisms of regulation of activity of bodies of state power as a complex of institutional, legal and administrative means, forms and administration methods, rational combination of which based on the system approach allows to change the normal regulation of the behavior of objects and subjects of administration on the regulatory impact of the subject for public relations is given.

It is established that the main problem is non-systemacy of the organizational-legal and administrative reform, subject discreteness of reforming and institutional asymmetry of the reforms content. The work proves that the unresolved challenge remains the classification mechanisms, forms, structures, approaches and instruments for regulation of activity of bodies of the state power aimed at solving the following administrative tasks: 1) formation of the integrated system of public authorities at central, regional, and sub-regional levels of administration, improvement of mechanisms of territorial administration in terms of decentralization; 2) creation of a modern model of rational interaction between bodies of the state power and bodies of local selfgovernment in terms of administrative reform in order to optimize procedures providing public (administrative, social, police, etc.) services, and the implementation of the rights and freedoms of citizens in the field of public administration; 3) organization of a modern system of training and retraining of personnel for maintenance of functioning of regulation mechanisms of state power bodies; 4) introduction of a new model of administrative-territorial division of the state; 5) systematization of means of the regulatory provision of the administrative reform implementation. 


\section{REFERENCES}

1. Averjjanov V. (2009) Ljudynocentrystsjka ideologhija jak osnova reformuvannja ukrajinsjkogho administratyvnogho prava $\mathrm{v}$ umovakh integhracijnogho procesu [Center-centered ideology as a basis for reforming Ukrainian administrative law in the context of the integration process]. Derzhava ta reghiony (Serija: Pravo), 2010, no. 2 , p. 87 .

2. Averjjanov V. (2009) Ljudynocentrystsjka ideologhija jak osnova reformuvannja ukrajinsjkogho administratyvnogho prava $\mathrm{v}$ umovakh integhracijnogho procesu [Center-centered ideology as a basis for reforming Ukrainian administrative law in the context of the integration process]. Derzhava ta reghiony (Serija: Pravo), 2010, no. 2, p. 92 .

3. Atamanchuk Gh. (2005) Ghosudarstvennoe upravlenye (orghanyzacyonno-funkcyonaljnye voprosy) : ucheb. posob. Moskwa [Public Administration Theory: A Lecture Course]. Юридическая литература.

4. Atamanchuk Gh. (2000) Ghosudarstvennoe upravlenye (orghanyzacyonno-funkcyonaljnye voprosy): ucheb. posob. [Public administration (organizational-functional issue): textbook. help]. Moskwa. Юридическая литература (in Russian).

5. Prykhodjko V. (2013) Mekhanizm derzhavnogho reghuljuvannja ta upravlinnja ekonomichnoju bezpekoju [The mechanism of state regulation and management of economic security]. Investyciji: praktyka ta dosvid, no. 15. pp. 6-8.

6. Radchenko O. (2013) Rodovi oznaky kateghoriji mekhanizm v socialjnykh naukakh [Generic attributes of the mechanism category in the social sciences]. Publichne upravlinnja: teorija ta praktyka, № 3. pp. 19-25.

7. Korotych O. (2006) Derzhavne upravlinnja reghionaljnym rozvytkom Ukrajiny [Public Administration of Regional Development of Ukraine ] Kharkiv:. Maghistr. (in Ukrainian)

7. Rudnicjka R. Sydorchuk O. 2014.Sutnistj ta zmist mekhanizmiv derzhavnogho upravlinnja ta pryncypiv jikh funkcionuvannja [The essence and content of the mechanisms of 
public administration and principles of their functioning]. Publichne upravlinnja: teorija ta praktyka. no. 4. pp. 50-60.

9. Prykhodchenko L. (2008) Sutnistj ponjatj mekhanizmiv derzhavy, derzhavnogho upravlinnja ta derzhavnogho reghuljuvannja [The essence of the concepts of mechanisms of the state, public administration and state regulation]. Aktualjni problemy derzhavnogho upravlinnja: zb. nauk.pr. no 3, pp. 269-274.

10. Fedorchak O. (2008) Klasyfikacija mekhanizmiv derzhavnogho upravlinnja [Classification of mechanisms of public administration]. Demokratychne vrjaduvannja : Naukov. visnyk LRIDU NADU. [Democratic Governance: Scientific. Bulletin of LRIDU NADU] (electronic journal), no. 1. Retrieved from: www.lvivacademy.com_O_Fedorchak.pdf. Accessed (5.11.2019).

11. Knjazjev V., Bakumenko V. (2002) Derzhavne upravlinnja: slovn.-dovidn. [Public administration: vocabulary reference]. Kyiv: UADU. (in Ukraine)

12. Nyzhnyk N. (1998) Systemnyj pidkhid v orghanizaciji derzhavnogho upravlinnja: navch. posib. [ Systematic Approach in Public Administration: Tutorial]. Kyiv: UADU. (in Ukraine)

13. Bashtannyk A. (2015) Konceptualjni zasady naukovogho analizu stanovlennja mekhanizmiv reghuljuvannja dijaljnosti orghaniv vlady v Ukrajini [Conceptual bases of the scientifically developed structure of regulation of power activity in Ukraine]. Efektyvnistj derzhavnogho upravlinnja: zb. nauk. pr. no. 43. pp. 281-286.

14. Meljnychenko V. (2004) Decentralizacija ta dekoncentracija publichnoji vlady na postradjansjkomu prostori: determinovanistj, znachennja, mezhi [Decentralization and deconcentration of public power in the post-soviet space: determination, meaning, limits]. Visnyk Khmeljnycjkogho instytutu reghionaljnogho upravlinnja ta prava, no 1-2, pp. 282-288.

15. Kom'jakov O. (2000) Derzhavne reghuljuvannja perekhidnoji ekonomiky [State control in a transition period economy] (PhD Thesis): Kyiv: Kyiv National Economic University.

16. Higher Attestation Commission (2007) Passports of specialties. HAC Bulletin of Ukraine. no 3, pp. 4-8. 
17. Bakumenko V. (2014) Pidkhid do vyznachennja pasportiv specialjnostej shljakhom systemnogho analizu derzhavnogho upravlinnja [An approach to the definition of specialty passports through a systematic analysis of public administration]. Aspekty publichnogho upravlinnja, no 3-4, pp. 5-9.

18. Merzljak A., Scryabina D. (2015) Derzhavna polityka skhidnojevropejsjkykh krajin u sferi jevrointeghraciji:perspektyvy adaptaciji dlja Ukrajiny [State Policy of Eastern European Countries in the Field of European Integration: Adaptation Prospects for Ukraine] Teorija ta praktyka derzhavnogho upravlinnja ta miscevogho samovrjaduvannja [The theory and practice of public administration and local self-government] (electronic journal), no. 1. Retrieved from: http://el-zbirn-du.at.ua/2015_1/13.pdf. Accessed (5.11.2019).

18. Shevchuk B. (2012) Jevropejsjki pryncypy nalezhnogho vrjaduvannja ta reforma systemy orghaniv vykonavchoji vlady $\mathrm{v}$ Ukrajini [European principles of good governance and reform of the executive power system in Ukraine]. Demokratychne vrjaduvannja. [Demokratychne vrjaduvannja] (electronic journal), no. 9. Rezhym from: http://www.lvivacademy.com/visnik9/ fail/Shevchuk_B.pdf. Accessed (5.11.2019).

19. Rebkalo V., Shkljar L. (2003) Politychni instytuty v procesi reformuvannja systemy vlady [Political institutions in the process of reforming the system of government]. Kyiv: Milenium. (in Ukraine).

\section{Information about the author:}

Alla Bashtannyk,

Candidate of Science in Public Administration, Deputy Director of the Dnipro Regional Branch,

National School of Judges of Ukraine 118, Gagarina ave., Dnipro, 49107, Ukraine ORCID ID: orcid.org/0000-0001-5691-2293 